УДК 341.645

DOI https://doi.org/10.32849/2663-5313/2020.5.62

Ольга Чепель,

канд. юрид. наук, адвокат,

доцент кафедри європейського права та порівняльного правознавства

Чернівецького начіонального університету імені Юрія Федьковича

\title{
ПРАВОВА ПРИРОДА КОНСУЛЬТАТИВНОГО ВИСНОВКУ ЄВРОПЕЙСЬКОГО СУДУ 3 ПРАВ ЛЮДИНИ
}

У иій статті розкрито поняття та зміст консультативного висновку Європейського суду з прав людини як рекомендаційного акта Європейського суду з прав людини на запит вищого суду уповноваженого державою-членом Ради Свропи з приниипових питань, які стосуються тлумачення або застосування прав і свобод, визначених Конвениією про захист прав та основоположних свобод людини 1950 року або протоколами до неї. Консультативний висновок є новим інструментом взаємодіі між судовим органом Ради Європи та начіональними судами і судовими установами держав-иленів Конвениії 1950 року, що передбачений у Протоколі № 16 до Конвениї̈ про захист прав та основоположних свобод людини 1950 р. У статті досліджено правовий механізм звернення національного судового органу держави-илена Ради Європи із запитом до Європейського суду з прав людини для отримання консультативного висновку та його вплив на вітчизняну правову систему. Зокрема, уповноважені виші суди можуть отримати консультативний висновок тільки після направлення відповідного запиту. Такий запит має відповідати певним умовам: запит має бути направлений виключно вищим судом, визначеним державою-учаснииею Конвениії; запит має стосуватися виключно приниипових питань щодо тлумачення або застосування прав і свобод, визначених Конвениією або протоколами до неї; запит може бути надісланий виключно щодо судової справи, яка перебуває у провадженні вищого суду. Консультативний висновок ухвалюється Великою Палатою Європейського суду з прав людини, але не має обов'язкової юридичної сили. Однак можливість отримання консультативного висновку Європейського суду з прав людини дасть змогу державі-илену розширити можливості для діалогу із Судом стосовно чіткого розуміння змісту норм Конвениї 1950 р. та їі протоколів для справедливого правосуддя на начіональному рівні, а також зменшить кількість звернень проти держави до Європейського суду з прав людини, що буде сприяти розвантаженню судового органу Ради Європи.

Ключові слова: права людини, правосуддя, Конвенція про захист прав та основоположних свобод людини, Протокол № 16, принцип субсидіарності

Постановка проблеми. В Україні нині є суспільний запит на справедливе правосуддя. Тому досить часто громадяни України звертаються до Свропейського суду з прав людини (далі - Суд, ЄСПЛ, Страсбурзький суд, судовий орган Ради Європи) з останньою надією на справедливе правосуддя, інколи навіть, помилково сприймаючи Страсбурзький суд як четверту судову інстанцію поряд 3 трьома національними. Тому очевидним $€$ той факт, що протягом останніх десятиліть виникла велика завантаженість справами Європейського суду з прав людини, де, як зазначає колишній голова Суду Гвідо Раймонді [1], майже 70\% завантаженості Суду є скарги з п'яти держав-членів Ради Свропи (Росії, Румунії, України, Туреччини, Італії). Отже, така ситуація вимагала реформування європейської системи правосуддя, тому 2 жовтня 2013 року в рамках Ради Європи був прийнятий Протокол № 16 до Конвенції про захист прав та основоположних свобод 1950 р. [2] (далі - Конвенції), який запровадив новий інструмент взаємодії між Судом та національними судами і судовими установами держав-членів Конвенції, згідно з яким вищим судовим установам надається можливість звернення за консультативним висновком до Європейського суду з прав людини 3 принципових питань, які стосуються тлумачення або застосування прав і свобод, визначених Конвенцією або протоколами до неї. Такий інструмент має на меті додатково сприяти посиленню взаємодії між Судом та національними органами влади і таким чином підтримуватиме виконання Конвенції у відповідності до принципу субсидіарності, однак, наскільки ефективний консультативний висновок ЄСПЛ як інструмент зниження звернень до ЄСПЛ та який його вплив на національну правозахисну систему, нині потребує комплексного аналізу. 
Аналіз останніх досліджень та публікацій. Окремі питання діяльності Свропейського суду з прав людини були предметом дослідження як вітчизняних, так і зарубіжних науковців, серед них - В. Буткевич, М. Гнатовський, Д. Гудима, К. Дзехциару, Т. Дудаш, В. Капустинський Л. Липачова, В. Манукян, Н. О’Миара, В. Мицик, Т. Нешатаєва, Н. Севастьянова, Т. Хартлі, Г. Юдківська та ін. Однак, незважаючи на значний науковий доробок щодо правового статусу Європейського суду з прав людини, його взаємодії з державами - членами Ради Свропи, третіми країнами, особливості консультативного висновку Страсбурзького суду, його значення для національних правових систем не досить висвітлені та потребують наукового дослідження.

Мета статті полягає в тому, щоб на основі норм міжнародного права, практики Страсбурзького суду, українського законодавства розкрити правову природу консультативного висновку Свропейського суду з прав людини, його місце та роль у вітчизняній системі правосуддя та на цій основі запропонувати рекомендації щодо удосконалення української правозахисної системи.

Виклад основного матеріалу дослідження. Набуття чинності 1 серпня 2018 року Протоколу № 16 до Конвенції про захист прав та основоположних свобод людини 1950 р. [3] (далі - Протокол № 16) розширило консультативну юрисдикцію Європейського суду 3 прав людини та демонструє динамічність розвитку європейської правозахисної системи. Адже це розширення консультативної юрисдикції ЄСПЛ спрямоване на досягнення двох цілей: скорочення надмірної завантаженості Страсбурзького суду і розширення діалогу між Судом і (вищими) національними судами.

Просування конструктивного діалогу між Європейським судом 3 прав людини та національними судами і судовими установами слугує інструментом впровадження норм Конвенції на національному рівні відповідно до принципу субсидіарності [4], який покладає «завдання забезпечення дотримання прав, закріплених у Конвенції, передусім на органи влади держав-учасниць, а не на Суд. Суд може та повинен втручатися тільки тоді, коли національні органи не можуть виконати це завдання» [5]. Саме тому у консультативному висновку Парламентської Асамблеї Ради Європи № 285 (2013 р.) зазначено, що Протокол № 16 покликаний зміцнити зв'язок між Європейським судом та найвищими судами держав-учасниць, створивши платформу для судового діалогу, таким чином сприя- ючи застосуванню національними судами практики Європейського суду; допомогти переходу з ex post (з лат. перед подією) на ex ante (з лат. після події) у вирішенні низки питань щодо тлумачення положень Конвенції на рівні держави, що у довготривалій перспективі дасть змогу зберегти «цінні ресурси» Європейського суду [6].

Очевидно, важливим нововведенням, запровадженим Протоколом № 16, стало надання можливості вищим судовим установам держав-учасниць звертатися до Свропейського суду за консультативними висновками щодо принципових питань, які стосуються тлумачення або застосування прав і свобод, визначених Конвенцією або протоколами до неї. При цьому кожна договірна держава визначає самостійно, у заяві на ім'я Генерального секретаря Ради Свропи, ті вищі судові установи, які матимуть право звертатися до Суду за наданням консультативних висновків, а також держава має право змінити ці вищі суди в будь-який момент [6].

В Україні згідно з Протоколом № 16 вищим судом визначено Верховний Суд України, який уповноважений правом звернення до Суду. Тоді як наприклад, Франція визначила: Конституційну раду, Державну раду та Касаційний суд; Грузія - Верховний суд Грузії та Конституційний суд Грузії; Вірменія - Конституційний суд Республіки Вірменія та Касаційний суд Республіки Вірменія; а Румунія - Верховний Суд касації та юстиції, Конституційний Суд та 15 апеляційних судів [7].

Однак ми погоджуємось 3 думкою кандидата юридичних наук Дмитра Гудими, що Протокол № 16 не обмежує це право держав, а тому можливі випадки, коли держава закріпить право «замовляти» такі висновки за судами, що мають обмежену компетенцію з розгляду справ про порушення прав і свобод. Говорячи про Україну, такими судами можуть стати не тільки Верховний Суд України, але й Конституційний Суд України. Але наскільки кардинально вплине надання їм повноважень звертатися до Суду за консультативними висновками у конкретних справах на рівень завантаженості Суду зверненнями проти України та на стан виконання нашою державою зобов'язань за Конвенцією? Як видається, такий вплив з огляду на компетенцію вказаних національних судів буде обмеженим [9].

Варто зазначити, що уповноважені вищі суди можуть отримати консультативний висновок тільки після направлення відповідного запиту до Секретаріату ЄСПЛ. При цьому Протокол № 16 та Регламент ЄСПЛ [8] визначає умови прийнятності такого 
запиту, зокрема: запит має бути направлений виключно вищим судом, визначеним державою-учасницею Конвенції; запит має стосуватися виключно принципових питань щодо тлумачення або застосування прав і свобод визначених Конвенцією або протоколами до неї; запит може бути надісланий виключно щодо судової справи, яка перебуває у провадженні вищого суду [3].

При цьому варто звернути увагу, що національний суд, який звертається із запитом, або судова установа, ухвалює рішення щодо зупинення провадження у справі в національному суді до отримання консультативного висновку Свропейського суду з прав людини. Однак тут є небезпека порушення права на доступ до правосуддя, оскільки, як слушно зазначає адвокат Артем Білоусов, важливо, щоб механізм звернення за консультативним висновком держава або учасники судового процесу не використовували для затягування вирішення справи [6].

Оскільки Страсбурзький суд чітко не окреслив перелік «принципових питань», стосовно яких можна отримати консультативний висновок, тому вважаємо, що це може бути ситуація, коли визначений суд або судова установа застосовують Конвенцію та прецедентне право Суду до спору, який вони розглядають з урахуванням доказів сторін з цього питання. Можливо, що відповідний суд або судова установа дійдуть висновку, що справа, на їхню думку, порушує нове питання права Конвенції, або факти справи не підпадають під пряме застосування прецедентного права Суду, або що існує непослідовність у прецедентному праві. За таких обставин відповідний суд або судова установа може скористатися можливістю подати запит щодо надання консультативного висновку. Важливим $є$ той аспект, щоб під категорією «принципових питань» не маскувались політичні питання, що може негативно вплинути на концепцію консультативного висновку.

Однак щодо змісту запиту, то він має бути обгрунтованим і в ньому повинні бути викладені: (а) предмет справи в національному суді та iï відповідні правові та фактичні обставини; (b) відповідні національні законодавчі положення; (c) відповідні питання Конвенції, зокрема, права або свободи, які є ключовими у справі; (d) якщо це є доречним, стислий виклад доказів сторін під час провадження в національному суді з цього питання; (е) якщо це можливо та доречно, власна думка суду або судової установи, які звертаються із запитом 3 цього питання, в тому числі будь-який аналіз, який він сам міг зробити з цього питання. Якщо суд, який подає запит, або судовий орган вважає, що запит вимагає термінового розгляду, він повинен повідомити про це Суд та вказати причини для подання запиту відповідно до прискореної процедури. Запит може бути поданий до Суду мовою провадження в національному суді, якщо вона є офіційною мовою Високої Договірної Сторони, якій належить суд, що подає запит, або судова установа. Проте, якщо мова не є офіційною мовою ЄСПЛ, переклад на англійську або французьку мову запиту повинен бути поданий у строк, встановлений Головою Суду [8].

Консультативний висновок щодо запиту, поданого відповідним судом або судовою установою, надається Великою Палатою Суду, створеною відповідно до правила 24 § 2 (h) Регламенту Суду. Проте важливо, щоб призначені суди або судові установи враховували, що запит щодо надання консультативного висновку спочатку розглядатиметься так званою «фільтраційною» колегією у складі п'яти суддів Великої Палати, яка визначає прийнятність запиту, тобто перевіряє, чи поданий до Суду запит стосується питання або принципових питань, пов'язаних 3 правами та свободами, визначеними Конвенцією та протоколами до неї, і чи відповідає він процедурним вимогам щодо його форми та змісту, тому колегія може підтвердити прийнятність запиту або відхилити такий запит, обгрунтувавши свою відмову [8].

Якщо колегія суддів приймає запит, Велика Палата Суду, загальний склад якої 17 суддів, більшістю голосів надає консультативний висновок, який повинен бути мотивованим та опублікованим. При цьому до складу колегії суддів та Великої Палати входить ех officio суддя, обраний від Високої Договірної Сторони, до якої належить суд чи судова установа, що звертається із запитом. У разі відсутності такого судді або якщо він не може брати участь у засіданнях, Голова Суду вибирає зі списку, поданого заздалегідь цією Стороною, особу, яка засідає як суддя. Також якщо консультативний висновок повністю або частково не виражає одностайної думки суддів, то кожний суддя має право викласти окрему думку [3].

Крім того, Комісар Ради Свропи з прав людини і Висока Договірна Сторона, до якої належить судова установа, що звертається із запитом, мають право подавати свої письмові зауваження і брати участь у будь-якому слуханні. Голова Суду в інтересах належного здійснення правосуддя може запропонувати будьякій іншій Високій Договірній Стороні або особі також подати свої письмові зауваження або взяти участь у будь-якому слуханні [8].

Слід підкреслити, що консультативний висновок Європейського суду з прав людини не має обов'язкової сили для вищого суду, 
який направив запит, але він може бути врахований у разі реалізації особою (зокрема, стороною процесу) її права на подання індивідуальної заяви до Свропейського суду в порядку, передбаченому ст. 34 Конвенції, а також міждержавних справ згідно зі ст. 33 Конвенції [2].

Тому К. Дзехциару та Н. О’Миара [10] не вважають прогресивним інструмент консультативного висновку ЄСПЛ, оскільки, на їхню думку, тягар, який ця процедура покладає на і без того перевантажений справами Страсбурзький суд, може привести до зволікання в розгляді наявних спірних справ та потенційно підірвати довіру національних судових органів до ЄСПЛ у разі відхилення запитів про надання консультативних висновків. Однак Янніка Яхн [11] вважає, що Протокол № 16 запровадив прогресивний інструмент (консультативний висновок - О.Ч.), що слугує механізмом для сприяння розвитку та узгодженості європейської судової практики з прав людини.

На наш погляд, консультативний висновок - це ще один інструмент загальноєвропейської системи захисту прав людини, який хоч і не має обов'язкової юридичної сили згідно з Протоколом № 16, однак буде мати значний вплив на національну систему правосуддя, якщо держави-члени Конвенції визнають його для себе як джерело права, це дасть можливість національним судам враховувати положення консультативного висновку під час здійснення правосуддя та не допустити порушення прав, передбачених Конвенцією про захист прав та основоположних свобод та протоколів до неї, що може зменшити кількість однопредметних заяв до Європейського суду $з$ прав людини, наприклад як у справі ЄСПЛ «Бурмич та інші проти України» [12].

Крім того, ідея зменшити завантаженість Суду не була би реалізована, якщо би пропоновані зміни не мали значення для «долі» заяв, які надходитимуть до нього. Так, «якщо заява до Суду скерована після провадження у справі, в якій консультативний висновок Суду був ефективно застосований, то очікується, що ті частини заяви, які стосуються питань, розглянутих у консультативному висновку, будуть визнані неприйнятними чи вилучені» 3 реєстру. За якими критеріями Суд буде оцінювати ефективність застосування консультативного висновку для вирішення справи на національному рівні, поки що невідомо [9].

Оскільки нині на вебпорталі практики Європейського суду розміщений лише один консультативний висновок, складений 10.04.2019 р. за запитом Касаційного суду Франції в жовтні 2018 р. щодо застосування ст. 8 Конвенції (право на повагу до приватного і сімейного життя), в контексті права прийомної матері бути визнаною законною матір'ю своєї сурогатної дитини (номер запиту Р162018-001). Суд дійшов висновку 3 цього питання, що «право дитини на повагу до приватного життя за змістом статті 8 Конвенції вимагає, щоб національне законодавство передбачало можливість визнання законних відносин між батьком і дитиною та з передбачуваною матір'ю, зазначеної під час народження» [13].

Також у 2019 році до ЄСПЛ був направлений другий запит від Конституційного суду Вірменії, який просив Європейський суд 3 прав людини надати консультативний висновок за статтею Кримінального кодексу країни, що передбачає покарання за повалення конституційного ладу. Зокрема, Конституційний суд Вірменії заявив, що його запит був зроблений у контексті двох справ щодо конституційності ст. 300.1 Кримінального кодексу, за якою порушено кримінальну справу проти колишнього Президента Вірменії Роберта Кочаряна [14]. Однак наразі консультативний висновок ще готується ЄСПЛ, а у запиті не було заявлено про застосування прискореної процедури.

\section{Висновки}

Таким чином, консультативний висновок Європейського суду з прав людини є рекомендаційним актом реагування Європейського суду з прав людини на запит вищого суду уповноваженого державою-членом Ради Європи щодо принципових питань, які стосуються тлумачення або застосування прав і свобод, визначених Конвенцією про захист прав та основоположних свобод людини або протоколами до неї.

Україна, яка, ратифікувавши Протокол № 16 до Конвенції про захист прав та основоположних свобод, запровадила для Верховного Суду України ще один інструмент для справедливості правосуддя, тобто направлення запиту для отримання консультативного висновку, однак не окреслила юридичний статус консультативного висновку для вітчизняної системи правосуддя. Тобто не визначила, який вплив може чинити такий висновок на українську систему правосуддя, тому рекомендовано внести зміни до статті 17 Закону України «Про виконання та застосування практики Європейського суду 3 прав людини», де доповнити норму про юридичну силу консультативного висновку ССПЛ у системі джерел права України.

Крім того, варто окреслити процесуальні аспекти впливу консультативного висновку для національного законодавства, зокрема важливо, щоб інструмент звернення 
за консультативним висновком держава або судові інстанції не використовували для затягування завершення розгляду справи У зв'язку з цим варто внести зміни до чинних процесуальних кодексів України, де визначити механізми взаємодії національних судів з Верховним Судом України саме щодо подання запиту на отримання консультативного висновку.

\section{Список використаних джерел:}

1. Україна увійшла у першу трійку за кількістю скарг проти неї в Свропейському суді з прав людини. URL: https://www.eurointegration.com. ua/news/2019/01/24/7091973/.

2. Конвенція про захист прав людини і основоположних свобод від 04.11.1950 p. URL: http:/ www.echr.coe.int/Documents/Convention_UKR.

3. Протокол № 16 до Конвенції про захист прав людини і основоположних свобод від 02.10.2013 p. URL: https://zakon.rada.gov.ua/laws/ show/994 002-13

4. Guidelines on the implementation of the advisory-opinion procedure introduced by Protocol No. 16 to the Convention (as approved by the Plenary Court on 18 September 2017). URL: https://www. echr.coe.int/Documents/Guidelines P16 ENG.pdf.

5. Interlaken Follow-up: Principle of Subsidiarity. Note by the Jurisconsult. URL: http://echr.coe.int/Documents/2010 Interlaken Follow-up ENG.pdf.

6. Білоусов А. Консультативні висновки ЄСПЛ: нові можливості у захисті прав і основоположних свобод? URL: https://yur-gazeta. com/publications/practice/sudova-praktika/ konsultativni-visnovki-espl-novi-mozhlivosti-uzahisti-prav-i-osnovopolozhnih-svobod.html.

7. Дроздов О., Дроздова О. Керівні принципи щодо впровадження процедури надання консультативного висновку, встановленої Протоколом
№ 16 Конвенції (затверджені на Пленарному засіданні Суду 18 вересня 2017 року). URL: https:// www.echr.com.ua/wp-content/uploads/2018/08/ Guidelines-P16.pdf

8. Регламент Європейського суду 3 прав людини в редакції від 19 вересня 2016 р. URL: https://www.echr.coe.int/Documents/Rules_ Court_RUS.pdf.

9. Гудима Д. Чи існує взаємозв’язок між підтриманням авторитету Страсбурзького суду та звуженням можливостей на звернення до нього? URL: http://www.c50.com.ua/article/chy-isnuyevzayemozvyazok-mizh-pidtrymannyam-avtorytetustrasburzkogo-sudu-ta-zvuzhennyam-mo.

10. Дзехциару К., О’Миара Н. Консультативная юрисдикция и Европейский суд по правам человека: волшебная пуля для диалога и контроля над документами? URL: https://www. cambridge.org/core/journals/legal-studies/article/ advisory-jurisdiction-and-the-european-court-ofhuman-rights-a-magic-bullet-for-dialogue-anddocketcontrol/E7BDA1704CCB5045CDB47F72C 5DFBCB7.

11. Jannika Jahn. Normative Guidance from Strasbourg Through Advisory Opinions. Deprivation or Relocation of the Convention's Core? URL:https:// www.zaoerv.de/74_2014/74_2014_4_a_821_846. pdf.

12. Рішення Європейського суду 3 прав людини у справі «Бурмич та інші проти України» №№ 46852/13, 47786/13, 54125/13, 2017 p. URL: https://minjust.gov.ua/m/4600.

13. Анализ: первое консультативное заключение Страсбургского суда по Протоколу № 16. URL: http://echrblog.blogspot.com/2019/05/theeuropean-courts-first-advisory.html.

14. ССПЛ отримав другий запит щодо надання консультативного висновку. URL: https://jurliga.ligazakon.net/news/188408_espchpoluchil-vtoroy-zapros-otnositelno-predostavleniyakonsultativnogo-zaklyucheniya.

This article describes the concept and content of the Advisory opinion of the European Court of Human Rights, as a recommendation act of the European Court of Human Rights to the request of the highest court authorized by a member state of the Council of Europe on fundamental issues relating to the interpretation or application of rights and freedoms defined by the Convention for the protection of human rights and fundamental freedoms or its protocols. The Advisory opinion is a new tool for interaction between the Strasbourg court and national courts and judicial institutions of the member States of the Convention, provided for in Protocol No. 16 to the Convention for the protection of human rights and fundamental freedoms of 1950. The article examines the legal mechanism of the national judicial authority of a member state of the Council of Europe requesting the European Court of Human Rights for an Advisory opinion and its impact on the domestic legal system. In particular, authorized higher courts can only obtain an Advisory opinion after a request has been made. Such a request must meet certain conditions: the request must be directed solely to the Supreme court, certain state-party to the Convention; the request must relate solely to fundamental issues of interpretation or application of the rights and freedoms defined in the Convention or its protocols; the request may be sent exclusively to the court case, which is pending before the Supreme court. The Advisory opinion is adopted by the Grand Chamber of the European Court of Human Rights, but is not legally binding.

However, the possibility of obtaining an Advisory opinion from the European Court of Human Rights will allow the member state to expand the opportunities for dialogue with the Court regarding a clearunderstanding of the content of the provisions of the Convention (1950) and its protocols for fair justice at the national level, as well as reduce the number of appeals against the state to the European court of human rights, which will help to unload the Court.

Key words: human rights, justice, Convention for the protection of Human Rights and Fundamental Freedoms, Protocol No. 16, principle of subsidiarity. 